about 3100 B.c. Its dimensions were about 60 metres by 60 metres, and its walls still stand about 10 metres high. It rests on a clay platform, and was found to be packed with votive offerings, among which were about 40,000 beads in a variety of material, though mostly of faience. There were also a large number of amulets, which are beautiful specimens of animal carving and not all paralleled at Ur and Uruk. A collection of alabaster idols consisted of about 200 complete figures, with some thousands of fragments.

\section{Excursion of the Geological Society of France}

A. R. LILLIE writes: The réunion extraordinaire of the Société Géologique de France was held this year on September 10-17 in the southern French Alps. There was an attendance of ninety-four members, who came from the following countries: France, Belgium, Britain, Czechoslovakia, India, Poland, Spain and Switzerland. The excursion, under the guidance of Profs. Gignoux, Lory, Moret, Raguin and Schneegans, was well organized and was a useful introduction to a territory of fascinating tectonic problems. The party met at Grenoble, where M. Gignoux outlined the objects of the meeting, and then went by motor-car to the Dévoluy. M. Lory there demonstrated the considerable extent of the pre-Senonian folding which he has elucidated during many years work. From Gap as centre, during the following three days, the excursion was conducted in localities situated in the ultra-Dauphinois zone and the sub-Briançonnais zone at Ancelle and in the Ubaye valley. The recent work done in this region, particularly that of Schneegans in the massif of the Grand Morgon, is very impressive in view of the complicated tectonics and the mountainous nature of the ground. Moving on to Briançon for the last three days of the excursion, the party had the opportunity of seeing something of the tectonics in the Briançonnais zone. The final day was spent at the col du Galibier, where all the tectonic elements are to be seen continued northwards into Savoie. An excellent memoire with numerous plates had been prepared by MM. Gignoux and Moret in collaboration with Lory and Schneegans, and a copy was presented to each participant. This memoire, entitled "Description Géologique du Bassin Supérieur de la Durance", appears to include much hitherto unpublished work, and should prove a valuable summary for geologists interested in Alpine tectonics.

\section{The Mellon Institute}

THE annual report of the Director of the Mellon Institute for the year March 1, 1937, to March 1, 1938, refers to the interest aroused in hydroxyethylapocupreine, a contribution of the Institute's department of research in pure chemistry. Semi-plant soale operations have been undertaken to provide material for more extensive clinical trials, and other new drugs prepared in the Institute have received clinical trials in cases of pneumonia and pneumococcic empyema. Research on alkyl, hydroxyalkyl and other derivatives of apocupreine is being actively pursued with the object of finding more efficient antipneu- mococcic drugs. Studies in the treatment of streptococcal and pneumococcal infections have been continued, and research on the variability of the tubercle bacillus has reached a point where it appears to be of some importance in diagnosing anomalous aspects of lung tuberculosis in the benign stages, an advance which may make it possible to use preventive and hygienic measures in time to stop development into the classical and more fatal forms. Seventy-two applied science programmes or fellowships were in operation in 1937-38, new fellowships on amines, anthracite industries, chemical hygiene, cotton, dielectrics, proteins and tar properties commencing operation in the year. Valuable contributions to the improvement of industrial health have been made by the attention given to the medical, engineering and legal aspects of the problems involved. A multiple fellowship on commodity standards has a programme directed to establishing standards for nearly 300 items of staple merchandise so as to provide known values for the consumer. The Cotton Research Foundation is investigating the chemical and physical properties and uses of the whole cotton plant. A new blue print paper has been developed, and a new resin, "Raolin," is also under development. A multiple fellowship on organic synthesis has been concermed with the preparation, properties and uses of a wide range of amines, solvents, intermediates and resins, including various alkylene alkylol and heterocyclic amines, propylene glycol derivatives, silicon and titanium esters of higher alcohols and vinyl resins for protective coatings.

\section{Industrial Development in 1937}

A SURver of Industrial Development for 1937 recently issued by the Board of Trade includes particulars of factories opened, extended and closed in 1937 with some figures for 1936, and indicates the extent to which industrial development in the form of new factories and factory extensions took place in Great Britain in 1937, together with the areas in which it occurred and the nature of the trades contributing to such development (H.M. Stationery Offices. 9d. net). The survey is limited to factories where 25 or more persons are to be or have been employed, and Government establishments set up in pursuance of the rearmament programme are excluded. The Survey shows that 541 new factories, employing 46,700 people, were established in 1937, as against 542 in 1936, employing 49,500 people. The number of factory extensions, however, increased from 185 to 237 and the number of factories closed decreased from 394 to 361. 94 of the new factories represent transfers from other areas and 66 of these are in Greater London. An attempt was made to ascertain the reasons for the location of the new factories. Convenience of premises was the reason given in 212 of the 416 cases for which particulars were obtained, suitability of labour coming next (67), proximity to other factories in the same industry (41), proximity to markets (34), cheap land, low rent or low rates (34), accessibility of raw materials (26), being the other reasons assigned in the relative order indicated. 